\title{
Ground Water Contamination by Crude Oil near Bemidji, Minnesota
}

Ground-water contamination by crude oil, and other petroleum-based liquids, is a widespread problem. An average of 83 crude-oil spills occurred per year during 1994-96 in the United States, each spilling about 50,000 barrels of crude oil (U.S. Office of Pipeline Safety, electronic commun., 1997). An understanding of the fate of organic contaminants (such as oil and gasoline) in the subsurface is needed to design innovative and cost-effective remedial solutions at contaminated sites.

A long-term, interdisciplinary research project sponsored by the U.G. Geological Survey (USGS) Toxic Substances Hydrology Program began in 1983 at a crude-oil spill site near Bemidji, Minnesota (fig. 1). The project involves research by scientists from the USGS and several academic institutions. This research is directed toward understanding the physical, chemical, and biological processes controlling the migration and fate of hydrocarbon contaminants in the subsurface. The goal is to provide information and methods to help evaluate the potential for, and long-term performance of, natural and enhanced bioremediation of hydrocarbon contamination across the nation.

The crude-oil spill site near Bemidji is one of the better characterized sites of its kind in the world. Results of research conducted on processes affecting the migration and fate of crude oil in the environment have provided fundamental knowledge that has been used to remediate similar sites worldwide. The Bemidji research project was the first to document that the extent of crude-oil contamination at a site can be largely limited by natural attenuation. Scientists studying and documenting natural attenuation at other contaminated sites have used many of the methods and approaches developed at the Bemidji site.

\section{Description and History of Site}

On August 20, 1979 approximately 16 kilometers northwest of Bemidji, Minnesota, the land surface and shallow subsurface were contaminated when a crude-oil pipeline burst, spilling about 1,700,000 L (liters) (about 10,700 barrels) of crude oil onto a glacial outwash deposit (fig. 1). Crude oil also sprayed to the southwest covering an approximately $7,500 \mathrm{~m}^{2}$ (square meter) area of land (spray zone). After cleanup efforts were completed about 400,000 L (about 2,500 barrels) of crude oil remained. Some crude oil percolated through the unsaturated zone to the water table near the rupture site (North oil pool, fig. 1). Some of this sprayed oil flowed over the surface toward a small wetland forming a second area of significant oil infiltration (South oil pool).

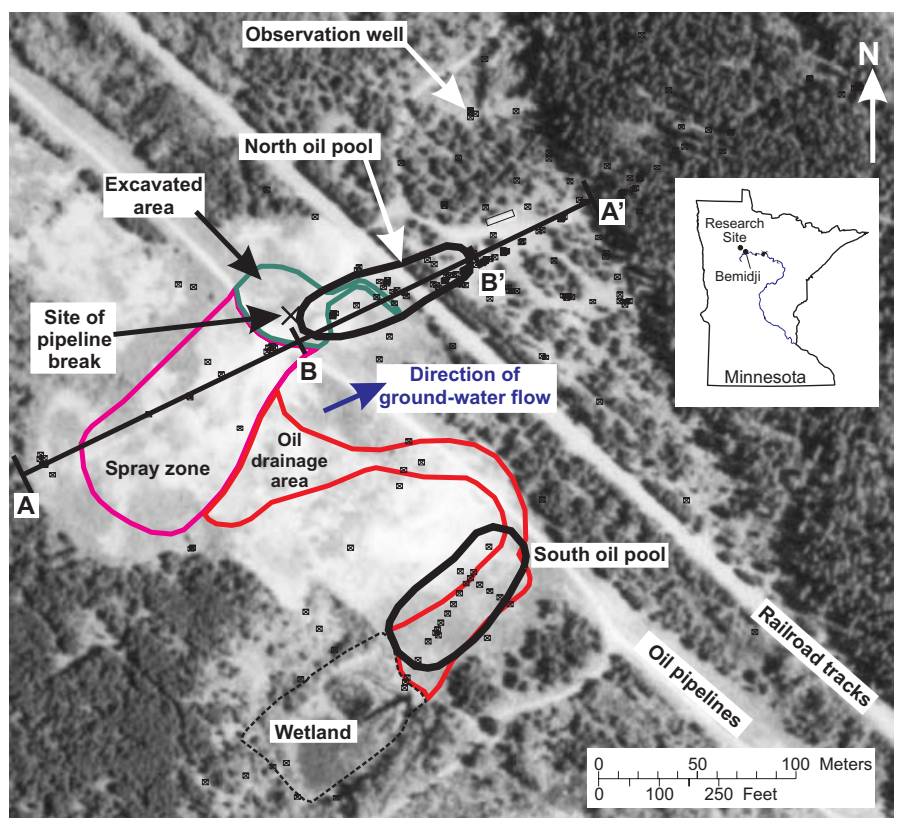

Figure 1. Features of the Bemidji, Minnesota crude-oil spill research site superimposed on a 1991 aerial photograph.

The land surface is a glacial outwash plain underlain by stratified glacial outwash deposits. The water table ranges from near land surface to about $11 \mathrm{~m}$ below the land surface. About 370 wells and test holes had been installed as of 1998 .

\section{Research Results}

The fate, transport, and multiphase flow of hydrocarbons depends on geochemical processes and on the processes of volatilization, dissolution, biodegradation, transport, and sorption (fig. 2). An interdisciplinary investigation of these processes is critical to successfully evaluate the migration of hydrocarbons in the subsurface. The investigation at the Bemidji site involved the collection and analysis of crude oil, water, soil, vapor, and sediment samples. The oil phase that occurs as floating product on the water table and as residuum on sediment grains provided a continued source of hydrocarbon to the ground-water and vapor plumes. Knowledge of the geochemistry of a contaminated aquifer is important to understanding the chemical and biological processes controlling the migration of hydrocarbon contaminants in the subsurface. Studies were also conducted to document the concentrations of gases in the unsaturated zone.

Multiphase-flow modeling was used to study the oil movement after the spill. Transport and biodegradation modeling was used to simulate the evolution of the plume, evaluate factors limiting biodegradation, and to develop a mass balance for 


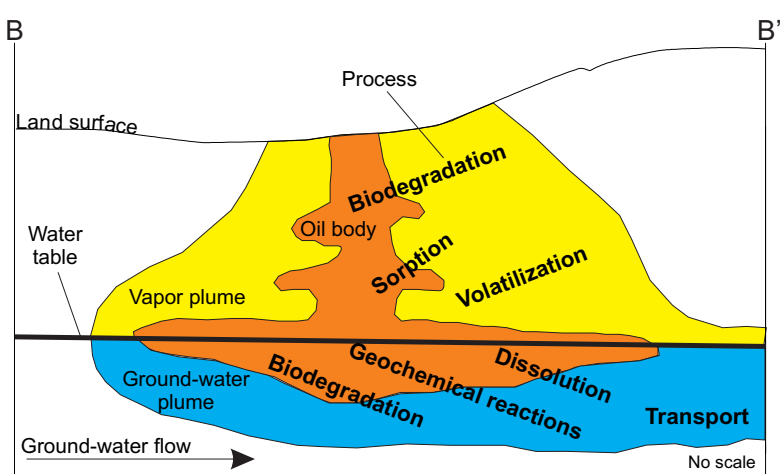

Figure 2. Processes critical to understanding the fate and transport of hydrocarbons in the subsurface at the Bemidji site.

contaminants at the site and thus evaluate the amount and rate of removal of hydrocarbons by biodegradation.

\section{Oil Phase}

Oil movement is affected by sediment properties, and their variability, which has resulted in a complex distribution of oil in the subsurface at the North oil pool (fig. 3). Geostatistical analysis and multiphase-flow simulations have been used to explain how spatial variability affects the oil distribution (Dillard and others, 1997). As of 1996, the leading edge of the oil floating on the water table at the North oil pool had moved about $40 \mathrm{~m}$ downgradient since the spill.

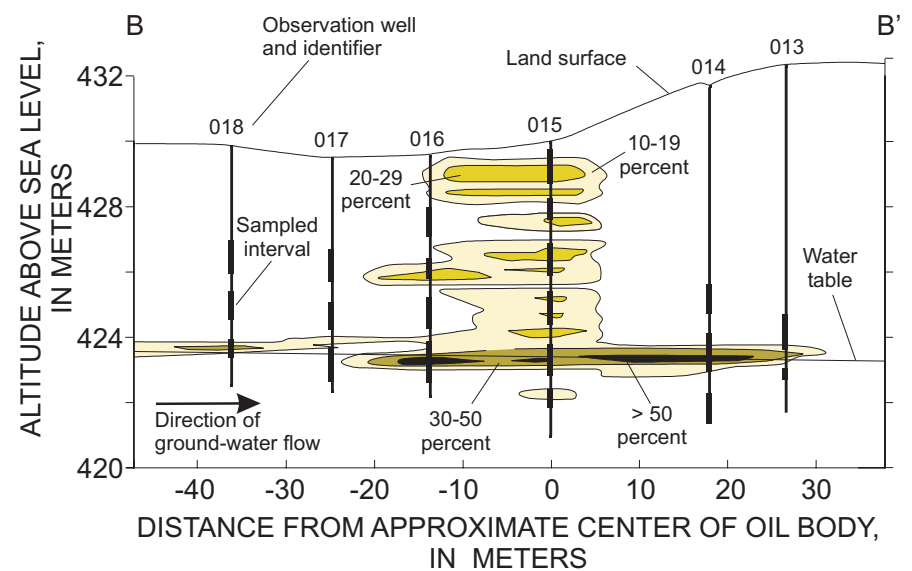

Figure 3. Oil saturation distribution at the north oil pool.

Degradation of the oil product has resulted in selective loss of soluble and volatile compounds through dissolution and volatilization. Mass loss rates of crude oil at different locations range from 0 to 1.25 percent per year. The total loss of oil mass was estimated at 11 percent from 1979-89 (Landon and Hult, 1991).

\section{Aqueous Phase}

Five geochemical zones have been identified at the North oil pool within the saturated zone (Baedecker and others, 1993; Bennett and others, 1993) (fig. 4). Zone 1 consists of oxygenated uncontaminated native ground water. Zone 2, which is below the spray zone, is characterized by low oxygen concentrations and high concentrations of total dissolved inorganic and organic carbon. Zone 3, beneath and immediately downgradient of the floating oil, consists of an anoxic plume of ground water containing high concentrations of hydrocarbons, dissolved man- ganese $\left(\mathrm{Mn}^{2+}\right)$, iron $\left(\mathrm{Fe}^{2+}\right)$, and methane $\left(\mathrm{CH}_{4}\right)$. Zone 4 , a transition zone from anoxic to oxygenated conditions, contains low concentrations of hydrocarbons as a result of aerobic degradation processes. Zone 5 consists of oxygenated water downgradient from the contamination plume that contains slightly higher concentrations of dissolved constituents, such as benzene, toluene, ethylbenzene, and xylene (BTEX).

Long-term monitoring of the plume since 1984 has shown that, near the water table, the concentration of total dissolved organic carbon (TDOC) and dissolved oxygen (DO) downgradient from the oil body has remained relatively stable suggesting that degradation of the plume has reached equilibrium. In the anoxic zone (Zone 3), concentrations of reduced chemical species $\mathrm{Mn}^{2+}, \mathrm{Fe}^{2+}$, and $\mathrm{CH}_{4}$ have increased with time, indicating a sequence of Mn reduction, Fe reduction, and methanogenesis. With depletion of $\mathrm{Mn}(\mathrm{IV})$ near the oil body, Mn reduction has become a less important reaction. The data show that both $\mathrm{Fe}(\mathrm{III})$ reduction and methanogenesis are major reactions in the anoxic plume (Baedecker and others, 1993).

Although these geochemical processes have changed over time, the plume has not migrated as far as predicted considering the ground-water flow velocities and sorption constants for these compounds (Baedecker and others, 1993). As of 1996, the leading edge of the plume of ground water containing a total BTEX concentration greater than 10 micrograms per liter had moved only about $200 \mathrm{~m}$ downgradient, whereas advective flow of ground water since the spill has been about $500 \mathrm{~m}$. The primary reason is that hydrocarbons have biodegraded under oxic and anoxic conditions.

The rate of removal of organic contaminants by natural attenuation and the factors that affect rates of biodegradation are important considerations in making decisions concerning cleanup of contaminated ground water. Biodegradation of petroleum-derived hydrocarbons in oxic and sub-oxic environments is generally considered a more efficient attenuation mechanism than is biodegradation in anoxic environments. However, research at this site has demonstrated that biodegradation in anoxic environments can remove substantial amounts of hydrocarbons from ground water (Lovley and others, 1989; Baedecker and others, 1993; Eganhouse and others, 1993; Cozzarelli and others, 1994).

\section{Vapor Phase}

Volatile oil components have left the subsurface through volatilization and biodegradation in, and diffusion through, the unsaturated zone. The distribution of gases (hydrocarbon, oxygen $\left(\mathrm{O}_{2}\right)$, carbon dioxide $\left(\mathrm{CO}_{2}\right)$, and $\left.\mathrm{CH}_{4}\right)$ in the unsaturated zone were quantified at the North oil pool during 1997 and used to identify three geochemical zones (fig. 4). Zone 6 exhibits near atmospheric concentrations of $\mathrm{O}_{2}$. Zone 7, a transition zone, is defined by lower concentrations of $\mathrm{O}_{2}$ (10-20 percent), hydrocarbon concentrations less than 1 part per million (ppm), and higher concentrations of $\mathrm{CO}_{2}$ (0-10 percent) and $\mathrm{CH}_{4}(0-10$ percent). Zone 8 , immediately above the oil body, is relatively anoxic and contains maximum concentrations of $\mathrm{CO}_{2}(>10$ percent), $\mathrm{CH}_{4}(>10$ percent), and hydrocarbon $(>1 \mathrm{ppm})$. 


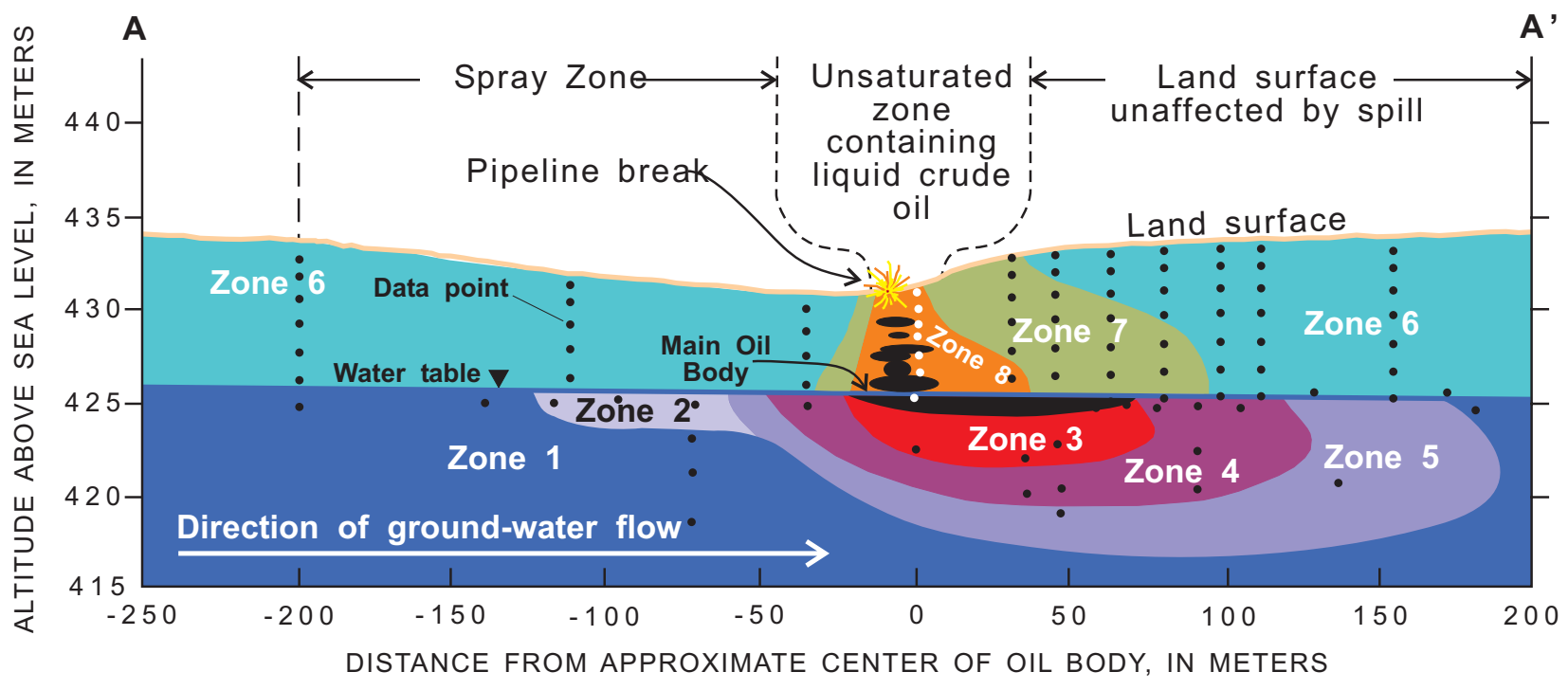

Figure 4. Geochemical zones in the unsaturated and saturated zones at the North oil pool, 1997 (Modified from Baedecker and others, 1993).

The distribution of gases at the North oil pool has changed considerably since the spill. For example, as of 1985 the leading edge of the plume of hydrocarbon vapors (concentrations $>1$ ppm, zone 7) in the unsaturated zone was about $150 \mathrm{~m}$ downgradient (Hult and Grabbe, 1988). As of 1997 the plume of vapors had receded to about $75 \mathrm{~m}$ downgradient (fig. 4) and the receding likely was due to aerobic biodegradation.

\section{Microbial Distributions}

In 1994, water and sediment samples were collected from a background location and six locations downgradient from the oil body for microbial biomass determinations (Essaid and others, 1995). The Most Probable Number method was used to enumerate microorganisms capable of degradation under differing redox conditions. In the background location, aerobes and fermenters were the only significant microbes detected. Within the plume the microorganism counts are consistent with the conceptual model of sequential aerobic, $\mathrm{Mn} / \mathrm{Fe}$ reduction, and methanogenesis degradation sequence. There are 104-105 iron-reducers per gram in the contaminated aquifer compared to none detected in the uncontaminated background area. Similarly there are 102 methanogens per gram in the plume and none detected in the background area. This result is similar to that of Godsy and others (1992) who reported a 100-fold increase in methanogens within a creosote plume. In general, greater numbers of microorganisms were found closer to the oil body and in the upper half of the plume. Denitrifiers and sulfate reducers are present in lower numbers than all other types of microbes, in accordance with the low availability of nitrate and sulfate in the ground water. The data were used to formulate a model of biodegradation of the contaminants coupled to growth of the microbial population.

\section{Modeling of Solute Transport and Biodegradation}

Numerical models that simulate transport and biodegradation processes are useful for integrating information collected in the field and for studying the relative importance of simultaneously occurring processes. It is difficult to develop an accurate mass balance for a contaminant, and thus to distinguish the amount and rate of removal by biodegradation, dilution, and sorption. If sufficient data are available, a numerical model can be used to help explore these questions, simulate the evolution of the plume, and evaluate factors limiting biodegradation.

A two-dimensional, multispecies solute-transport model including multiple substrate uptake, sequential terminal electron acceptor use, and cellular nutrient limitation of biomass growth (BIOMOC, Essaid and Bekins, 1997) was developed to analyze the evolution of the ground-water contaminant plume at the Bemidji site (Essaid and others, 1995). Simulations included the biodegradation of volatile (VDOC) and nonvolatile (NVDOC) fractions of DOC by aerobic processes, $\mathrm{Mn} / \mathrm{Fe}$ reduction, and methanogenesis. Geochemical evidence indicates that these processes are important in degrading the oil. Model parameter estimates were constrained by published Monod kinetic parameters, theoretical yield estimates, and field biomass measurements. Despite considerable uncertainty in the model parameter estimates, results of simulations reproduced the general features of the measured ground-water plume (fig. 4) and the measured constituent concentrations (fig. 5). For the simulation shown in figure 5, 46 percent of the TDOC introduced into the aquifer was degraded after 13 years. Aerobic degradation accounted for 40 percent of the TDOC degraded and anaerobic processes accounted for 60 percent: 5 percent by Mn reduction, 19 percent by Fe reduction, and 36 percent by methanogenesis. The model results indicate that anaerobic processes account for more than one-half of the removal of DOC at this site, consistent with the geochemical evidence.

\section{Contributions of Research}

- Research at this site has provided a comprehensive documentation of natural attenuation of hydrocarbons in a contaminated aquifer under both aerobic and anaerobic conditions. Project results are an often-cited example of natural attenuation, promoting its widespread adoption for use to remediate oil and gasoline contaminated sites. 

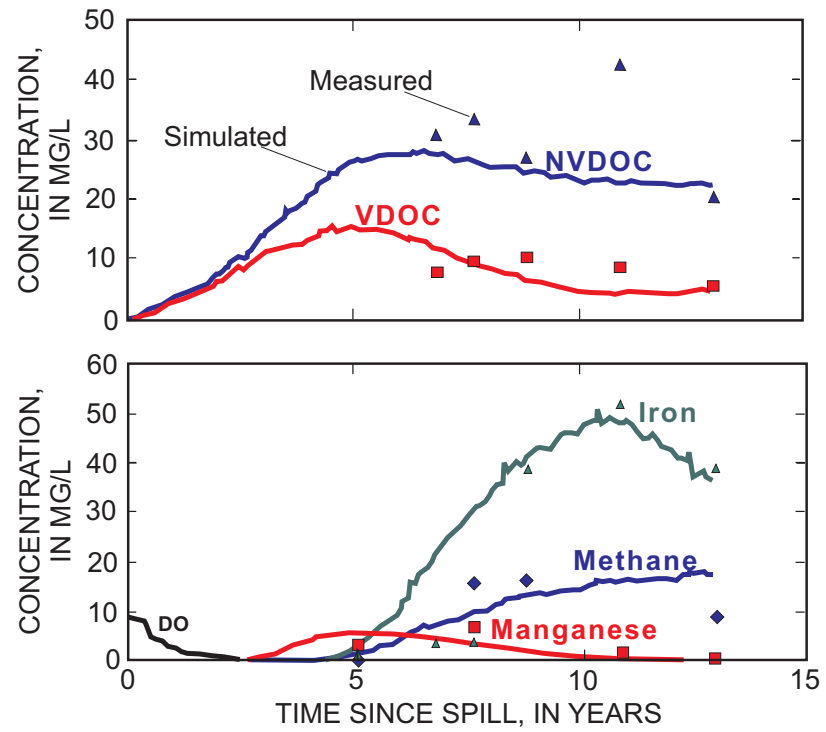

Figure 5. Simulated and measured concentrations of selected constituents $\mathbf{3 6}$ meters downgradient from the center of the oil body.

- Research results from this project are directly applicable to decisions to use natural attenuation to remediate similar sites, to design performance monitoring, and to prioritize sites for remedial action, which may result in less expensive remedial actions.

- The freezing drive shoe sampler, developed at the Bemidji site by Murphy and Herkelrath (1996), enables efficient recovery of saturated, unconsolidated sandy sediments; recovery of such samples was not possible using standard coring methods. The method enabled estimation of oil saturation (the fraction of pore space occupied by oil) in the subsurface.

- The comprehensive study of the oil distribution in the unsaturated and saturated zones at the Bemidji site is unique. New methods were developed to determine the fraction of the pore space occupied by oil, water, and air in unconsolidated sediments. The oil distribution data have been used to test numerical models of multiphase flow.

- A two-dimensional, multispecies solute-transport model code with biodegradation (BIOMOC) was developed to quantify natural rates of biodegradation, to evaluate natural attenuation as a long-term remedial strategy, and to design performance monitoring. This code can be readily applied to other systems and has been used at several other sites within the United States.

\section{Selected References}

Baedecker, M.J., Cozzarelli, I.M., Eganhouse, R.P., Siegel, D.I., and Bennett, P.C., 1993, Crude oil in a shallow sand and gravel aquifer, III- Biogeochemical reactions and mass balance modeling in anoxic groundwater: Applied Geochemistry, v. 8, p. 569-586.

Bennett, P.C., Siegel, D.I., Baedecker, M.J., and Hult, M.F., 1993, Crude oil in a shallow aquifer, 1-Aquifer characterization and hydrogeochemical controls on inorganic solutes: Applied Geochemistry, v. 8, p. 529-549.

Cozzarelli, I.M., Baedecker, M.J., Eganhouse, R.P., and Goerlitz, D.F., 1994, Geochemical evolution of lowmolecular-weight organic acids derived from the degradation of petroleum contaminants in groundwater: Geochimica et Cosmochimica Acta, v. 58, p. 863-877.

Dillard, L.A., Essaid, H.I., and Herkelrath, W.N., 1997, Multiphase flow modeling of a crude-oil spill site with a bimodal permeability distribution: Water Resources Research, v. 33, p. 1617-1632.

Eganhouse, R.P., Baedecker, M.J., Cozzarelli, I.M., Aiken, G.R., Thorn, K.A., and Dorsey, T.F., 1993, Crude oil in a shallow sand and gravel aquifer, II-Organic geochemistry: Applied Geochemistry, v. 8, p. 551- 567.

Essaid, H.I., and Bekins, B.A., 1997, BIOMOC, A multispecies solute- transport model with biodegradation: U.S. Geological Survey Water- Resources Investigations Report 97-4022, 77 p.

Essaid, H.I., Bekins, B.A., Godsy, E.M., Warren, E., Baedecker, M.J., and Cozzarelli, I.M., 1995, Simulation of aerobic and anaerobic biodegradation processes at a crude oil spill site: Water Resources Research, v. 31, p. 3309-3327.

Godsy, E. M., Goerlitz, D.F., and Grbic-Galic, D., 1992, Methanogenic biodegradation of creosote contaminants***, Ground Water, v. 30, p. 232-242.

Hult, M.F., and Grabbe, R.R., 1988, Distribution of gases and hydrocarbon vapors in the unsaturated zone, in, Ragone, S.E., ed., U.S. Geological Survey Toxic Substances Hydrology Program-Proceedings of the Technical Meeting, Cape Cod, Massachusetts, October 21-25, 1985: U.S. Geological Survey Water-Resources Investigations Report 81-4188, p. C21-C26.

Landon, M.K., and Hult, M.F., 1991, Evolution of physical properties and composition of a crude oil spill, in Mallard, G.E., and Aronson, D.A., eds., U.S. Geological Survey Toxic Substances Hydrology Program***, Monterey, California, March 11-15, 1991: U.S. Geological Survey Water-Resources Investigations Report 91-4034, p. 641-645.

Lovley, D.R., Baedecker, M.J., Lonergan, D.J., Cozzarelli, I.M., Phillips, E.P., and Siegel, D.I., 1989, Oxidation of aromatic compounds coupled to microbial iron reduction, Nature, v. 339, p. 297-299.

Murphy, F., and Herkelrath, W.N., 1996, A sample-freezing drive shoe for a wire line piston core sampler: Ground Water Monitoring and Remediation, v. 16, no. 3, p. 86-90.

Smith, S.E., and Hult, M.F., 1993, Hydrogeologic data collected from a crude-oil spill site near Bemidji, Minnesota, 1983-91: U.S. Geological Survey Open-File Report 93-496, 158 p.

\section{For more information contact:}

District Chief, U.S. Geological Survey 2280 Woodale Drive, Mounds View, Minnesota 55112

Phone: (612) 783-3100
Additional information on the U.S. Geological Survey Bemidji Crude-Oil Research Project is available on the internet via the World Wide Web at http://wwwmn.cr.usgs.gov/bemidji/ Additional information on the U.S. Geological Survey Toxic Substances Hydrology Program is available at http://toxics.usgs.gov/toxics/ 